\title{
Benign Reproductive System Neoplasm
}

National Cancer Institute

\section{Source}

National Cancer Institute. Benign Reproductive System Neoplasm. NCI Thesaurus. Code C7617.

A non-metastasizing neoplasm that arises from the male or female reproductive system. Representative examples include benign prostate phyllodes tumor, benign Sertoli cell tumor, uterine corpus leiomyoma, and benign ovarian serous tumor. 